УДК 37.016:784.3]:159.922.75-053.6

DOI:

Ольга Рябова, аспірант кафедри педагогіки мистецтва та фортепіанного виконавства Начіонального педагогічного університету імені М.П. Драгоманова, м. Київ

\title{
ДОСЛІДЖЕННЯ СФОРМОВАНОСТІ МУЗИЧНО-СТИЛЬОВИХ УЯВЛЕНЬ ПІДЛІТКІВ - УЧАСНИКІВ КАМЕРНОГО ОРКЕСТРУ
}

У статті висвітлюються особливості діагностування рівнів сформованості музично-стильових уявлень за певними критеріями та їх показниками. Вони допомагають визначити наявність, кількісну характеристику, міру і ступінь сформованості досліджуваного феномену в учнів підліткового віку - учасників камерного оркестру. Автор пропонує власні методи дослідження музично-стильових уявлень $і$ надає рівневу характеристику їх сформованості, яка відображає особливості діяльності підлітків у складі камерного оркестру.

Ключові слова: музично-стильові уявлення; критерії сформованості; показники вимірювання; методи діагностування; рівнева характеристика.

Jim. 5.

Olha Ryabova, Postgraduate Student of the Pedagogy of the Art and Piano Performance Department

National Mykhaylo Drahomanov Pedagogical University, Kyiv

\section{RESEARCH OF FORMATION OF MUSIK AND STYLE NOTIONS OFTEENAGE STUDENTS, PARTICIPANTS OF CHAMBER ORCHESTRA}

The article deals with the peculiarities of diagnosing the levels of formation of music and style notions of teenagers, the members of a chamber orchestra. Formation of music and style ideas is a topical issue of contemporary music pedagogy. However, the methods of introducing a stylistic approach into the education of a musician-performer are investigated only in a limited number of works. The issue of formation of teenage music and style notions by means of collective music-making remains poorly investigated. The author diagnoses the existing level of the investigated phenomenon formation which reflects the peculiarities of the activity of teenage pupils as part of a chamber orchestra. The article defines the following criteria for music and style notions formation of teenagers, members of a chamber orchestra: a level of interest in a conscious style corresponding performance of musical orchestrial works; the degree of mastering musical-analytical and musical-performing skills necessary for playing in a chamber orchestra; the ability to diagnose and improve the quality of their own style corresponding performance of chamber orchestral music. Every criterion includes the several indicators of measurement which allow to identify the presence, quantitative characteristics, the level and degree of formation of music and style notions of teenagers, members of a chamber orchestra. The article considers the methods that allow to investigate certain properties of this phenomenon according to the determined indicators and to diagnose the existing state of its formation in the teenage students. The author provides a level characteristic of music and style notions formation among teenagers, members of a chamber orchestra. Study outcome analysis by all the specified criteria and their indicators showed the presence of predominantly low level of formation of music and style notions formation among teenagers. The author believes it necessary to study further the peculiarities of collective music-making in order to provide a theoretical underpinning, development and experimental testing of the music and style notions formation method among teenagers, members of a chamber orchestra.

Keywords: music and style notions; formation criteria; indicators of measurement; diagnostic methods; level characteristic.

П остановка проблеми. У музичному навчанні цілеспрямоване формування музично-стильових уявлень $\epsilon$ наріжним каменем розвитку музичного мислення особистості і необхідною умовою виховання професійної майстерності музиканта-виконавця. Але для успішного впровадження методів педагогічного впливу на функціонування музичностильових уявлень у виконавській діяльності підлітків - учасників камерного оркестру необхідно виявити наявність, кількісну характеристику, міру і ступінь сформованості даного феномену за допомогою певних критеріїв та показників вимірювання.

Аналіз останніх досліджень і публікацій. У музичній педагогіці дослідження музичностильових уявлень музиканта-виконавця грунтуються на теоріях фундаторів стилезнавства (Б. Асаф'єв, М. Михайлов, Б. Яворський) та працях мистецтвознавців, присвячених питанням стилевідповідності інтерпретацій музичних творів (В. Медушевський, В. Москаленко, Є. Назайкінський). 
Проблемам формування виконавського стилю присвяченіпраці Л. Ауера, М.Берлянчика, К. Стеценка, К Флеша, А. Ямпольського, Ю. Янкелевича. Важливість колективного музикування для розвитку музичного мислення музикантавиконавця підкреслюється у наукових розробках Т. Свирської, Г. Турчанінової, В. Федоришина. Проте конкретні методи застосування стильового підходу у процесі педагогічного керування музично-виконавською діяльністю учнів досліджені лише в окремих працях В. Буцяк, О. Щербініної.

Мета статті - розглянути методи діагностування рівнів сформованості музичностильових уявлень підлітків - учасників камерного оркестру за визначеними критеріями та їх показниками.

Виклад основного матеріалу дослідження 3 повним обгрунтвання отриманих наукових результатів. За визначенням науковців, критерій - це “ознака, на підставі якої здійснюється оцінка, визначення або класифікація чого-небудь; мірило" [3, 364]. У свою чергу, критерії мають специфічні ознаки, за якими вони відрізняються, котрі називаються показниками. У “Тлумачному словнику сучасної української мови" поняття “показник” розглядається як “1. Свідчення, доказ, ознака чогось. 2. Наочні дані про результати якоїсь роботи, якогось процесу; дані про досягнення в чомусь. Дані, які свідчать про кількість чого-небудь” $[3,544]$.

Отже, ми визначаємо такі критерії сформованості музично-стильових уявлень підлітків - учасників камерного оркестру:

- міра зацікавленості в усвідомленому стилевідповідному виконанні музичних оркестрових творів;

- ступінь оволодіння музично-аналітичними та музично-виконавськими вміннями, необхідними для гри в камерному оркестрі;

- здатність до діагностики та корекції якості власного стилевідповідного виконання камерної оркестрової музики.

Перший критерій - міра зачікавленості в усвідомленому стилевідповідному виконанні музичних оркестрових творів - включає такі показники:

1) ступінь інтересу до стилевідповідного виконання музичнихоркестрових творів;

2) обсяг музично-теоретичних та музичноісторичних знань.

Інтерес до втілення музичного стилю у власному виконанні спонукає підлітків до активного пізнання музичних явищ в історичному контексті їх розвитку і усвідомленого застосування практичних вмінь та навичок. Ступінь інтересу до стилевідповідного виконання музичних оркестрових творів відображає свідоме ставлення підлітків до власної музичної діяльності і впливає на якість їх гри у складі камерного оркестру.

Загальна поінформованість в галузі історії та теорії музики служить підгрунтям для розуміння особливостей музично-стильових систем різних історичних епох. Наявний обсяг музичноісторичних та музично-теоретичних знань, якими володіють учні підліткового віку, впливає на ступінь стилевідповідності виконання ними музичних оркестрових творів і виявляє міру зацікавленості в цьому.

Другий критерій визначення рівнів сформованості музично-стильових уявлень підлітків у колективному музикуванні, це ступінь оволодіння музично-аналітичними та музично-виконавськими вміннями, необхідними для гри в камерному оркестрі. Він включає такі показники:

1) здатність до стильової атрибуції музичних творів;

2) здатність до інтонаційно-смислового втілення музичного образу;

3) міра володіння виконавсько-руховими уміннями в рамках технологічних моделей музичних стилів.

Запорукою успішного відтворення музики виконавцем $\epsilon$ чітке уявлення ii стильової приналежності, котра визначає вирішення художніх та технічних завдань певним способом. Здатність до стильової атрибуції виявляється у вмінні розрізняти музичні стилі і аналізувати їх характерні властивості для усвідомлення виконавсько-технологічних моделей музичностильових систем різних епох.

Основою музичного стилю $є$ його образна природа, що виражається в інтонації, у якій “закодовано узагальнюючий зміст типізованих зворотів музичного мовлення" [1, 78]. За допомогою засобів виразності виконавець втілює звуковий образ, виявляючи інтонаційні ознаки того чи іншого стилю. Здатність до інтонаційносмислового втілення музичного образу виявляється у вмінні свідомого застосування засобів виразності в певних музично-стильових системах.

Гра в камерному оркестрі вимагає особливо прискіпливого ставлення до використання виконавських прийомів у колективному музикуванні і потребує визначених рухово-ігрових навичок. Вони повинні відповідати стильовим акустично-динамічнимпринципам звуковидобування, 


\section{ДОСЛДЖЕННЯ СФОРМОВАНОСТІ МУЗИЧНО-СТИЛЬОВИХ УЯВЛЕНЬПІДЛТККІВ - УЧАСНИКІВ КАМЕРНОГООРКЕСТРУ}

які стосуються штрихової техніки, артикуляції, аплікатури, вібрації, фразування, динаміки. Міра володіння виконавсько-руховими вміннями в рамках технологічних моделей музичних стилів виявляється уздатності до оперування технічними засобами виконання у контексті їх художньої доцільності.

Третій критерій визначення рівнів сфрмованості музично-стильових уявлень підлітків - учасників камерного оркестру, це - здатність до діагностики та корекиії якості власного стилевідповідного виконання камерної оркестрової музики. Він включає такі показники:

1) здатність до регуляції емоційного стану в процесі опанування стилевідповідним виконанням камерної оркестрової музики;

2) здатність до самоконтролю та самооцінки в процесі гри в камерному оркестрі;

3) оцінка міри стилевідповідності власного виконання музичних оркестрових творів.

Гра оркестрових творів різної стильової приналежності вимагає від виконавця здатності до віднаходження відповідного емоційного стану. Здатність до регуляції емоційного стану в процесі опанування стилевідповідним виконанням камерної оркестрової музики виявляється у вмінні коригувати свої власні відчуття в залежності від iii стильового забарвлення з метою закріплення позитивного досвіду.

За визначенням науковців, самоконтроль полягає в "забезпеченні необхідних актів корекції” $[2,152]$ у відповідності до зазначених зразків, а самооцінка "фіксує відповідність або невідповідність результатів засвоєння навчальної ситуаці1” $[2,154]$. Здатність до самооцінки та самоконтролю стилевідповідного виконання камерної оркестрової музики полягає у постійному аналізі та співставленні уявного та реального результату власної гри учнів підліткового віку і коригуванні їх професійних дій у процесі максимального виявлення стильових особливостей музичних творів.

Колективне музикування вимагає від підлітків дотримання принципів ансамблевої взаємодії, які впливають на застосування конкретних прийомів художньої та технічної майстерності для стилевідповідного виконання камерної оркестрової музики. Оцінка міри стилевідповідності власного виконання музичних оркестрових творів виявляється у здатності підлітків до оцінювання власних умінь та навичок з точки зору доцільного їх застосування в рамках виконавськотехнологічних моделей певних музичних стилів.

Отже, ми визначили всі критерії та їх показники, необхідні для дослідження сформованості музично-стильових уявлень підлітків - учасників камерного оркестру. Всі розроблені нами критерії складають цілісну єдність і дозволяють діагностувати три рівні сформованості досліджуваного феномену.

Високий рівень сформованості музичностильових уявлень підлітків - учасників камерного оркестру передбачає глибоку зацікавленість учнів в усвідомленому стилевідповідному виконанні музичних оркестрових творів, великий обсяг музичноісторичних та музично-теоретичних знань; широко розвинені здатності до стильової атрибуції та інтонаційно-смислового втілення музичного образу і досконале володіння виконавськоруховими уміннями в рамках технологічних моделей музичних стилів; яскраво виражену здатність до регуляції емоційного стану в процесі опанування стилевідповідним виконанням камерної оркестрової музики, постійне здійсненні самоконтролю та самооцінки в процесі гри в камерному оркестрі та завжди адекватну оцінку міри стилевідповідності власного виконання музичних оркестрових творів.

Середній рівень сформованості музичностильових уявлень підлітків - учасників камерного оркестру характеризується невеликою зацікавленістю учнів в усвідомленому стилевідповідному виконанні музичних оркестрових творів, обмеженим обсягом музично-історичних та музично-теоретичних знань; слаборозвиненими здатностями до стильової атрибуції та інтонаційно-смислового втілення музичного образу, недостатньо досконалим володінням виконавсько-руховими уміннями в рамках технологічних моделей музичних стилів; неяскраво вираженою здатністю до регуляції емоційного стану в процесі опанування стилевідповідним виконанням камерної оркестрової музики, нерегулярним здійсненням самоконтролю та самооцінки в процесі гри в камерному оркестрі, не завжди адекватною оцінкою міри стилевідповідності власного виконання музичних оркестрових творів.

Низький рівень сформованості музичностильових уявлень підлітків - учасників камерного оркестру колективному притаманний тим учням, котрі відрізняються незацікавленістю в усвідомленому стилевідповідному виконанні музичних оркестрових творів, наявністю лише фрагментарних знань з історії та теорії музики; нерозвиненими здатностями до стильової атрибуції та інтонаційно-смислового втілення музичного образу, неволодінням виконавсько-руховими вміннями в рамках технологічних моделей 
музичних стилів; нездатністю до регуляції емоційного стану в процесі опанування стилевідповідним виконанням камерної оркестрової музики, невмінням здійснювати самоконтроль та самооцінку в процесі гри в камерному оркестрі та неадекватним оцінюванням міри стилевідповідності власного виконання музичних оркестрових творів.

Для діагностування наявних рівнів сформованості музично-стильових уявлень підлітків - учасників камерного оркестру було здійснено педагогічне дослідження. Для отримання його результатів ми застосували певні методи, котрі враховували специфіку музичнонавчального процесу учнів підліткового віку на заняттях камерного оркестру.

Задля визначення ступеню сформованості досліджуваного феномену за першим критерієм було застосовано анкетування та тестування. Аналіз отриманих відповідей на питання анкети та результатів виконання завдань тестів дозволив визначити рівень музично-історичної та музичнотеоретичної поінформованості підлітків учасників камерного оркестру та виявити ступінь сформованості їх інтересу до стилвідповідного виконання музичних оркестрових творів.

Визначення ступеню сформованості музичностильових уявлень підлітків - учасників камерного оркестру за другим та третім критеріями потребувало проведення лабораторного дослідження у формі педагогічного спостереження за практичною діяльністю учнів. Задля визначення сформованості досліджуваного феномену за першим показником другого критерію (здатність до стильової атрибуції музичних творів) було застосовано метод проблемно-перцептивних завдань з використанням музичної вікторини. Визначення рівнів сформованості досліджуваного феномену за другим та третім показниками другого критерію (здатність до інтонаційно-смислового втілення музичного образу і міра володіння виконавськоруховими уміннями в рамках технологічних моделей музичних стилів) потребувало застосування наступних методів: 1) творчі завдання; 2) вивчення продуктів діяльності; 3 ) педагогічний консиліум.

Задля визначення рівнів сформованості досліджуваного феномену за показниками третього критерію були застосовані такі методи, як вивчення продуктів діяльності, бесіди, педагогічний консиліум та порівняльні оцінки.

Дослідження рівнів сформованості музичностильових уявлень підлітків - учасників камерного оркестру за другим та третім показником другого критерію та всіма показниками третього критерію здійснювалося за допомогою експертної групи. До її складу ввійшли керівники камерних оркестрів та викладачі струнно-смичкових відділів навчальних закладів, що брали участь в експерименті.

Висновки. Аналіз результатів дослідження засвідчив наявність переважно низького рівня сформованості музично-стильових уявлень підлітків за всіма визначеними критеріями та їх показниками. Це доводить, що у розповсюджених методах роботи 3 учнівськими камерними оркестрами стильовий підхід майже не використовується. Адже проблема формування музично-стильових уявлень підлітків ще малодосліджена, і методичне забезпечення шляхів іiі вирішення в умовах роботи камерного оркестру фактично відсутнє. Отже, ми вважаємо за необхідне подальше дослідження особливостей колективного музикування задля теоретичного обгрунтування, розробки та експериментальної апробації методики формування музичностильових уявлень підлітків - учасників камерного оркестру.

\section{ЛІТЕРАТУРА}

1. Берлянчик М. М. Основы воспитания начинающего скрипача Мышление. Технология. Творчество: Учебное пособие. / М. М. Берлянчик. - СПб.: Изд-во “Лань”, 2000. - 256 с. (Учебники для вузов. Специальная литература).

2. Власова О. І. Педагогічна психологія: Навч. Посібник / О. І. Власова. - К.: Либідь, 2005. $400 \mathrm{c}$.

3.Загнітко А. П., Щукіна I. А. Тлумачний словник сучасної української мови. / А. П. Загнітко, I. А. Щукіна. - Донецьк: ТОВ “ВКФ “БАО”, 2009. $-960 \mathrm{c}$.

4. Савчин М. В. Загальна психологія: навч. посіб./ М. В. Савчин. - К.: Академвидав, 2012. 464 с. (Серія “Альма-матер”).

5. Щербініна О. М. Теорія та практика музичного стилю: Навчально-методичний посібник. / О. М. Щербініна. - Ніжин, НДУ, 2006, $87 \mathrm{c}$.

\section{REFERENCES}

1. Berlianchik, M. M. (2000). Osnovy vospytaniya nachinyiuschego skripacha: Myshlenie. Tekhnologiya. Tvorchestvo: Uchebnoe posobie [Fundamentals of education novice violinist Thinking. Technology. Creativity: Tutorial]. St.Petersburg: Izd-vo "Lan", 256 p (Uchebniki dlya vuzov. Spetsialnaya literatura). [in Russian].

2. Vlasova, O. I. (2005). Pedahohichna 
psykholohiia: Navch. Posibnyk [Pedagogical Psychology: Teaching. Manual]. Kyiv: Lybid, 400 p. [in Ukrainian].

3. Zahnitko, A. P. \& Shchukina, I. A. (2009). Tlumachnyi slovnyk suchasnoi ukrainskoi movy [An Explanatory Dictionary of Modern Ukrainian Language]. Donetsk: TOV "VKF"BAO" Publ., 960 p. [in Ukrainian].

4. Savchyn, M. V. (2012). Zahalna psykholohiia: navch. Posib [General Psychology: Teach. Manual]. Kyiv: Akademvydav, 464 p. (Seriia “Alma-mater"). [in Ukrainian].

5. Shcherbinina, O. M. (2006). Teoriia ta praktyka muzychnoho styliu: Navchalnometodychnyi posibnyk [Theory and practice of musical style: A teaching manual]. Nizhyn, NDU Publ., 87 p. [in Ukrainian].

Стаття надійшла до редакції 28.01.2019

УДК 372.879

DOI:

Марія Дзіковська, аспірант, директор Природничого коледжу Львівського національного університету імені Івана Франка

\section{ПРОБЛЕМА ПРОФЕСІЙНОЇ ПІДГОТОВКИ ФАХІВЦІВ У ПЕДАГОГІЧНІЙ ТЕОРІЇ}

У статті здійснено теоретичний аналіз проблеми професійної підготовки фахівиів у вітчизняних наукових дослідженнях. Показано, щзо професійна підготовка фахівиів у науковій літературі досліджується у різних напрямах. Зазначено, ще професійна підготовка фахівців різного профілю містить спільні недоліки, поява яких зумовлена низкою суперечностей, які існують в освітньому процесі закладу вищої освіти. Запропоновано авторське визначення поняття "професійна підготовка фахівців природничих спецінальностей”.

Ключові слова: професійна підготовка; професійна освіта; педагогічна теорія; заклади вищої освіти. Jim. 15.

Mariya Dzikovska, Postgraduate Student, Head of Natural Sciences College, Lviv Ivan Franko National University

\section{THE PROBLEM OF PROFESSIONAL TRAINING OF SPECIALISTS IN PEDAGOGICAL THEORY}

The article describes the theoretical analysis of professional training of specialists in the scientific researches. It shows that professional training in scientific literature is being researched in various areas (education, art, natural sciences, engineering, sphere of service, industrial branches, etc.). Training is considered by researchers as: an important condition for the education improvements; poly-aspect professional education, that is involving fundamental knowledge; a system of organizational and pedagogical activities; the unity of content, structure, goals of teaching the students, the ways of realizing the acquired knowledge, skills and abilities in professional activity; an organization and methodical process of adopting the students' professional competence; pedagogical process in university education; activities that ensure professional readiness of future specialist, etc.

The professional training in different fields contains common disadvantages (unsystematic application in different technologies of teaching, implementation methods, insufficient level of of professional competence, educational process separation from production needs, lack of interconnection problems between general and higher education). The author identified common disadvantages of the professional training in educational process, their appearance is due to a number of contradictions (the author identified contradictions); noted about deficiencies needs to be eliminated in order to improve the quality of professional training. The author proposes a definition of the concept "professional training in natural sciences", which reflects professional training specificity in certain area of a higher education institution.

Keywords: professional training; professional education; pedagogical theory; institutions of higher education.

П остановка проблеми. Входження України у світовий освітній простір зумовило необхідність становлення нової освітньої парадигми, що передбачає нові підходи, відносини, поведінку тощо. Існуюча система професійної підготовки склалася в епоху нового часу і заснована на передаванні знань, сприйнятті та усвідомленні їх змісту. Нова європейська культура - культура галузева, раціональна, монологічна, утилітаристська. За цією логікою кваліфікація - результат професійної підготовки, що передбачає наявність у випускника необхідного рівня сформованості професійних умінь і навичок. 3 іншого боку - роботодавцям потрібна не кваліфікація, а компетентність як сукупність навичок, що притаманні кожному 